\title{
Wheat: A New Natural Host for the Mal De Río Cuarto Virus in the Endemic Disease Area, Río Cuarto, Córdoba Province, Argentina
}

\author{
P. E. Rodriguez Pardina, M. P. Giménez Pecci, and I. G. Laguna, INTA, Instituto de Fitopatología y Fisiología \\ Vegetal, 5119 Coronel Olmedo, Córdoba, Argentina; E. Dagoberto, Yanasuy, Las Heras 345, 2600, Venado Tuerto, \\ Pcia, de Santa Fé, Argentina; and G. Truol, INTA, Córdoba, Argentina
}

\begin{abstract}
Rodriguez Pardina, P. E., Giménez Pecci, M. P., Laguna, I. G., Dagoberto, E., and Truol, G. 1998. Wheat: A new natural host for the Mal de Río Cuarto virus in the endemic disease area, Río Cuarto, Córdoba Province, Argentina. Plant Dis. 82:149-152.

The fijivirus known as "Mal de Río Cuarto" that affects corn is endemic to the area of Río Cuarto, Cordoba Province, Argentina. One of the preferred species for the development of its vector, the insect Delphacodes kuscheli Fennah, is wheat. In this area, wheat plants with deformed leaves, spikes and spikelets, shortened internodes, leaves with serrated borders, and sterile spikelets were detected, suggesting the possibility that Mal de Río Cuarto Virus could also be infecting this crop. Samples originating in Río Cuarto, Sampacho, and La Carlota (Córdoba Province) that showed symptoms, were analyzed by double-antibody sandwich enzyme-linked immunosorbent assay (DAS-ELISA), polyacrylamide gel electrophoresis, and electron microscopy, confirming, for the first time, the occurrence of the disease in wheat. The frequency of the disease was assessed in random samples from 14 wheat plots located in the Department of Río Cuarto (Córdoba Province). The samples were analyzed using the DASELISA immunoenzymatic technique, and the disease was detected in the majority of the fields assessed, with levels of incidence that ranged between 2.5 and $24 \%$. We must be aware of the presence of this virus in the wheat crop, where it appears to play a double role in the epidemiology of the disease, acting both as a virus reservoir and as a preferred host for the development of populations of the vector virus, $D$. kuscheli.
\end{abstract}

Additional keywords: Mal de Río Cuarto virus, reservoir, wheat

"Mal de Río Cuarto" is the most important disease in maize in Argentina, and it can account for yield losses higher than $70 \%$ in the years of its greatest incidence (14). The disease is caused by a member of the subgroup II, genus Fijivirus Reoviridae family (12,30). It was initially thought to be a geographic strain of the maize rough dwarf virus (MRDV) detected in Italy (6), but molecular hybridization tests showed no complementation between them in at least 7 of the 10 genomic fragments (5).

Mal de Río Cuarto virus (MRCV) has 65- to 70-nm diameter icosahedric particles that contain 10 segments of doublestranded RNA (19). It is naturally transmitted by the insect Delphacodes kuscheli Fennan (Homoptera: Delphacidae) in a persistent, propagative way, and this form

Corresponding author: P. E. Rodriguez Pardina E-mail: postmaster@ifitovir.inta.gov.ar

This work was carried out with funds supplied by the PROMARC Project of INTA and CONICET

Accepted for publication 17 September 1997.

Publication no. D-1997-1203-01R

(C) 1998 The American Phytopathological Society of transmission constitutes the initial source of the inoculum $(24,26)$. Transmission by seeds has not yet been reported. It has been detected in 12 species of weeds of the families Poaceae and Cyperaceae found in the endemic area of the disease, among them Eleusine indica (L.) Gaer, Cynodon dactylon (L.) Pers, Sorghum halepense (L.) Pers, Cyperus cayennensis (Lam) Britt, Eragrostis viriscences Pers, Digitaria sanguinalis (L.) Scop, Cenchrus equinatus L., Cyperus rotundus L., Setaria geniculata (L.) Beauv, Arundo donax L., Echinochloa colonum (L.) Link, and Setaria verticillata (L.) Beauvois $(13,22,25$, 27); and in sorghum Sorghum bicolor L. Moench (10,20), millet Panicum milliaceum L., foxtail millet Setaria italica (L.) Beauv. $(16,17,25)$, and oat Avena sativa L. (9). Studies carried out in the disease endemic area $(15,23,24)$, showed that the vector's populations develop mainly in oats and wheat, then migrate to maize plants in their first stages of growth. This suggested that wheat may participate in the virus epidemiology. This, and the detection of plants with uncertain symptomatology, prompted the present research, which aimed to detect and identify the Mal de Río Cuarto virus in wheat crops in the endemic disease area (the Río Cuarto department in the Province of Córdoba, Argentina).

\section{MATERIALS AND METHODS}

Source of inoculum and symptoms. The incidence of Mal de Río Cuarto was assessed in wheat plots located in Río Cuarto, La Carlota, Sampacho, Espinillo, and Las Vertientes, in the province of Cordoba. Virus identification was carried out in samples of plants exhibiting symptoms at the vegetative or reproductive stage. Wheat plants were found in fields in Río Cuarto, Sampacho, and La Carlota which, in the vegetative stage, showed a large number of tillers, with shortening of the internodes, which gave them a stunted appearance (Fig. 1A) and short, erect, leathery leaves with enlarged veins (Fig. 1B). At the reproductive stage, plants had short internodes and showed enlarged walls. The leaves had serrated borders and curled in on themselves, giving them a corkscrew appearance (Fig. 1C). The spikes were found to be partially or totally sterile, and had shortened, curved rachis (Fig. 1D ). Plants with similar symptoms were found in Pergamino and Colón (Buenos Aires Province) and Diego de Alvear (Santa Fe Province). The identification tests began with this material. Samples were also taken to determine the incidence of the disease in wheat fields in the areas of Rio Cuarto, La Carlota, Sampacho, Espinillo, and Las Vertientes (Province of Córdoba).

Serology. Virus purification. Roots of infected maize, collected from corn fields, when plants were flowering, were the source of tissue for virus extraction. One hundred grams of root were ground in a mortar with 4 vol of $0.2 \mathrm{M}$ sodium-potassium phosphate buffer, $\mathrm{pH}$ 7.0, containing $5 \mathrm{mM}$ EDTA and $10 \mathrm{mM}$ sodium sulfite (extraction buffer), then squeezed through a cheesecloth. The homogenate was mixed with $1 \mathrm{vol}(400 \mathrm{ml})$ of $\mathrm{CCl}_{4}$, stirred for 30 min, and clarified by a 10-min centrifugation at $10,000 \times g$. The supernatant was centrifuged for $2 \mathrm{~h}$ at $75,000 \times g$, and pellets were resuspended in $12 \mathrm{ml}$ of extraction buffer and clarified at $10,000 \times \mathrm{g}$ for $10 \mathrm{~min}$. The supernatant obtained was ultracentrifuged for $1 \mathrm{~h}$ at $100,000 \times g$. Pellets were resuspended in $2 \mathrm{ml}$ of a $0.1-\mathrm{M}$ 
sodium-potassium phosphate buffer $\mathrm{pH} 7.0$ containing $5 \mathrm{mM}$ EDTA, and layered onto cesium sulfate gradients from 20 to $50 \%$ (from 5 in 5) for $2 \mathrm{~h} 30 \mathrm{~min}$. at $90,000 \times g$. The light scattering bands observed at approximately $30 \%$ density were diluted in $10 \mathrm{vol}$ of the same buffer, and centrifuged for $1 \mathrm{~h}$ at $100,000 \times g$. The pellet obtained was resuspended in a $0.1 \mathrm{M}$ potassium phosphate buffer, pH 7.0. All the protocol was carried out at $4^{\circ} \mathrm{C}$ with sterilized materials. Virus concentrations were estimated by spectrophotometer using an extinction coefficient of 5 .

Antiserum production. Polyclonal antiserum was produced by injecting rabbits with 3 doses of 20 to $25 \mu \mathrm{g}$ of viral protein at 18-day intervals. Each dose consisted of 2 intramuscular injections and various subcutaneous ones in the loin. The first immunization was made with Freund's complete adjuvant. For the other two, incomplete adjuvant was used. Bleeding was done 21 days after the last dose.
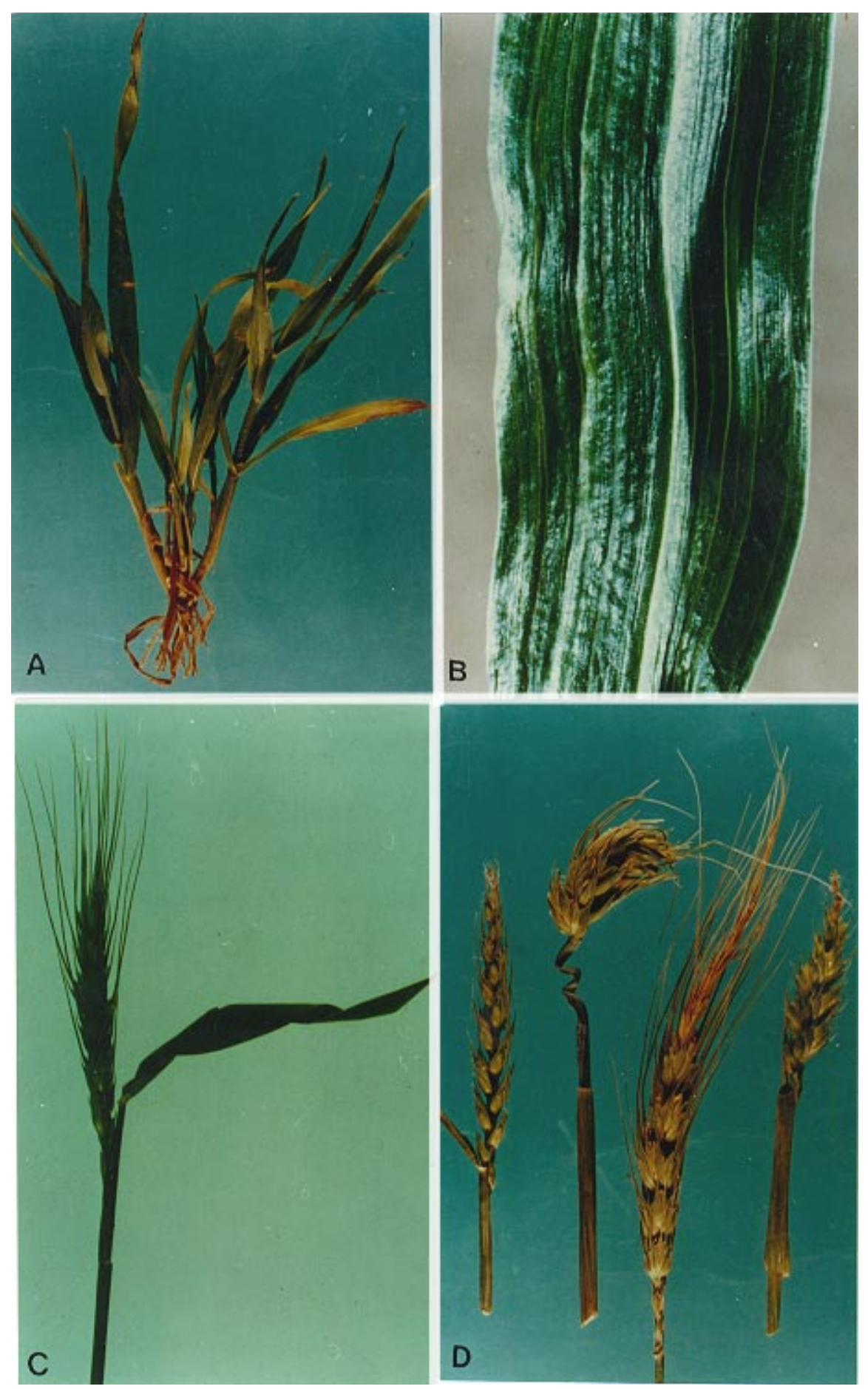

Fig. 1. Wheat plants with (A) shortened internodes and stunted aspect; (B) enlarged veins; (C) curled wheat leaves, with corkscrew appearance; and (D) partial sterility, curved spikes, and shortening of rachis.
From the serum obtained, gammaglobulin was purified by ammonium sulfate precipitation and later DEAE sephacel (Sigma Chemical Co., St. Louis) chromatography in half-strength phosphate-buffered saline (PBS; $0.02 \mathrm{M}$ phosphate plus $0.15 \mathrm{M} \mathrm{K}-\mathrm{NaCl}, \mathrm{pH} 7.4)$. It was adjusted at a final concentration of $1.0 \mathrm{mg} / \mathrm{ml}$ (optical density $\left.[\mathrm{OD}]_{280}=1.4\right)$. One $\mathrm{ml}$ of the above immunoglobulin $\mathrm{G}$ (IgG) was conjugated to alkaline phosphatase (type VII T, Sigma Chemical Co.) according to the original protocol by Clark and Adams (4). The antiserum reacted by double-antibody sandwich enzyme-linked immunosorbent assay (DAS-ELISA) in the presence of the MRCV maize antigen with high absorbency values (8), showed no reaction in the presence of maize dwarf mosaic potyvirus, (MDMV), but did react slightly with maize leaf infected with French origin MRDV. The immunosorbent electron microscopy (ISEM-D) of the antiserum reacted with roots of maize infected with Italian origin MRDV (M. P. Giménez Pecci and R. G. Milne, unpublished data).

Sample preparation. Leaf and root samples were ground in PBS $+0.05 \%$ Tween $20+2 \%$ polyvinyl pyrrolidone (PVP) at a $1: 4(\mathrm{wt} / \mathrm{vol})$ dilution.

ELISA (4). ELISA plates (Nunc-Immunoplate MaxiSorp, 96 wells) were coated with $1 \mu \mathrm{g} / \mathrm{ml}$ of IgG in $0.05 \mathrm{M}$ sodium carbonate $(\mathrm{pH}=9,6)$ and incubated for $4 \mathrm{~h}$ at $37^{\circ} \mathrm{C}$; the antigen was added to the wells and incubated for $18 \mathrm{~h}$ at $5^{\circ} \mathrm{C}$. The specific gammaglobulin for MRCV conjugated with alkaline phosphatase was added at a dilution of $1 / 1000$ in conjugate PBS $+0.05 \%$ Tween $20+2 \%$ PVP $+0.2 \%$ chicken egg albumin and was incubated for $4 \mathrm{~h}$ at $37^{\circ} \mathrm{C}$ for $60 \mathrm{~min}$. After adding the substrate $(0.75 \mathrm{mg} / \mathrm{ml}$ p-nitrophenyl phosphate [Sigma Chemical Co.] in $10 \%$ diethanolamine, $\mathrm{pH}$ 9.8), the reaction was quantified using a Dynatech MR4000 ELISA plate spectrophotometer. Samples were considered positive when $\mathrm{OD}_{450}$ values were higher than 0.100 or the mean of the healthy controls plus three times the standard deviation (six healthy controls were used per plate).

Three washings with PBS $+0.05 \%$ Tween 20 were performed between steps and $100 \mu$ were added to each well in all steps.

PAGE. In order to confirm the presence of the virus, roots of DAS-ELISA positive plants were analyzed with polyacrylamide gel electrophoresis (PAGE) for the detection of RNA according to the Giordano et al. protocol (11) modified by Giménez Pecci (8). Positive and negative controls were DAS-ELISA-positive maize and DAS-ELISA-negative wheat plants, respectively.

Sample preparation. Samples were ground in a ratio of $1: 4(\mathrm{wt} / \mathrm{vol})$ in PBS containing 2\% PVP and $0.05 \%$ Tween 20 . Two hundred $\mu \mathrm{l}$ of the aqueous phase were 
mixed with $200 \mu \mathrm{l} \mathrm{LiCl}$ buffer $+1 \%$ sodium dodecyl sulfate (SDS) and $10 \mathrm{mM}$ EDTA; $400 \mu \mathrm{l}$ of phenol chloroform 1:1 were added and samples were vortexed, heated at $56^{\circ} \mathrm{C}$ for $10 \mathrm{~min}$, and centrifuged at $16,000 \times g$ for $30 \mathrm{~min}$. One $\mathrm{ml}$ ethanol was added to the resulting supernatant (+/$200 \mu \mathrm{l}$ ), mixed vigorously, and kept at $20^{\circ} \mathrm{C}$ for $18 \mathrm{~h}$. It was centrifuged again at $16,000 \times g$ for $30 \mathrm{~min}$, and the pellet was kept and dried at $37^{\circ} \mathrm{C}$. Finally, it was dissolved in $20 \mu \mathrm{l}$ sample buffer (Tris- $\mathrm{HCl}$, $0.06 \mathrm{M}, \mathrm{pH} 6.8+5 \%$ 2-mercaptoethanol + $3 \%$ glycerol $+3 \%$ SDS $+0.0 .1 \%$ bromophenol blue).

A polyacrylamide 1 gel, composed of a $5 \%$ stacking gel in $0.125 \mathrm{M}$ Tris- $\mathrm{HCl}$ buffer, $\mathrm{pH} 6.8,+0.1 \%$ SDS and a $10 \%$ running gel in $0.375 \mathrm{M}$ Tris- $\mathrm{HCl}$ buffer, pH $8.7+0.1 \%$ SDS $10 \%(29: 1)$ was run. in a Mini PROTEAN II Electrophoresis Cell (Bio-Rad Laboratories, Richmond, CA) at

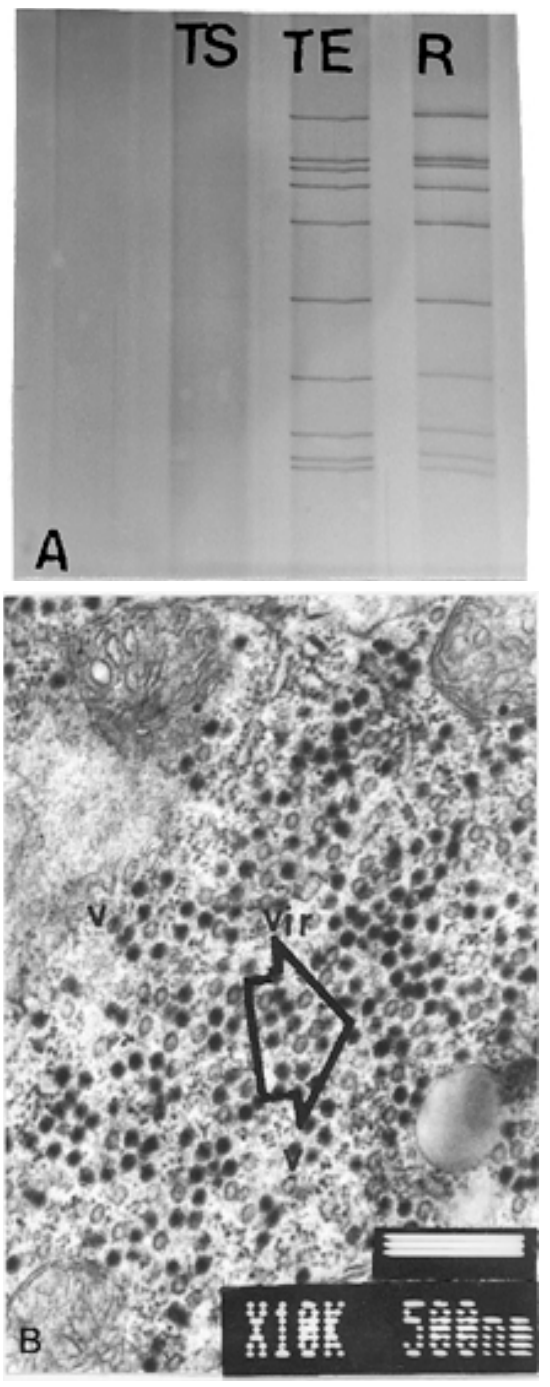

Fig. 2. (A) dsRNA fragments of "Mal de Río Cuarto" virus in infected wheat, observed in polyacrylamide gel electrophoresis in polyacrylamide gels with silver staining. References $\mathrm{R}=$ roots of positive wheat, $\mathrm{Te}=$ positive control, and Ts = healthy wheat. (B) Viroplasma (Vir) and complete and incomplete virus particles (V) in phloem parenchyma cells.
$11 \mathrm{~mA}$ for $11 \mathrm{~h}$ in Tris-glycine buffer (0.025 M Tris, 0.2 M glycine, $\mathrm{pH} 8.9+$ $0.1 \%$ SDS). Then the gel was intensely washed, fixed for $30 \mathrm{~min}$ with $0.5 \%$ acetic acid in $10 \%$ ethanol, stained with $0.011 \mathrm{M}$ $\mathrm{AgNO}_{3}$ for 30 min under gentle agitation, and developed with a solution composed of $0.75 \mathrm{M} \mathrm{NaOH}$ and $0.76 \%$ formaldehyde.

Electron microscopy. Inclusions of small pieces of leaves were prepared in Spurr resin for observation with the electron microscope, fixed with $2 \%$ paraformaldehyde/glutaraldehyde in $0.1 \mathrm{M}$ ca-

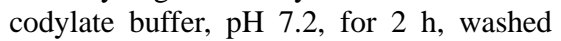
three times (15 min each) with $0.05 \mathrm{M}$ cacodylate buffer, and postfixed with $1 \%$ $\mathrm{OsO}_{4}$ (osmium tetroxide) in $0.05 \mathrm{M}$ cacodylate buffer for $2 \mathrm{~h}$. They were gradually dehydrated in a 30, 50, 70, and $90 \%$ acetone series from 15 to $20 \mathrm{~min}$ each, and in $100 \%$ acetone three times for $15 \mathrm{~min}$ each. Finally, they were infiltrated in acetone/Spurr (1:1) for $2 \mathrm{~h}$, then in pure Spurr all night, to be later polymerized in pure Spurr at $70^{\circ} \mathrm{C}$ for $24 \mathrm{~h}$ (29). Sections were cut on a RMC MT6000-XL microtome with a diamond knife, mounted on copper grids, stained with $2 \%$ uranyl acetate and lead citrate, and observed in an electron microscope (Jeol JEM 1200 EX II).

Disease frequency studies. Frequency studies were carried out during two consecutive crops in 1993 and 1994. Ten plots were sampled in Río Cuarto, La Carlota, and Sampacho (Department of Río Cuarto) in the first year, and four plots in Espinillo, Sampacho, and Las Vertientes (Department of Río Cuarto) in the second year. Thirty random samples were collected along the diagonal in each plot, and each of them was analyzed with the DAS-ELISA test.

\section{RESULTS AND DISCUSSION}

Serological tests gave positive results in plants with symptoms in the presence of the antiserum used. Absorbency values for positive samples ranged from $\mathrm{OD}_{410} 0.122$ to 2.000 in the analysis of leaves, and between $\mathrm{OD}_{410} 0.163$ and 2.000 in that of roots. Healthy controls showed absorbency values between 0.023 and 0.050 in leaves and between 0.031 and 0.056 for roots. The DAS-ELISA test was shown to be appropriate for the detection of Mal de Río Cuarto virus in wheat, as it could detect the virus both in leaf and in root tissues. No non-specific reactions were observed in healthy wheat plants.

In the PAGE analysis, the 10 characteristic double-stranded RNA segments were observed with a pattern which coincided with the one observed in the positive control and agreeing with the one described for MRCV in corn when it was first associated with maize rough dwarf fijivirus (19). Bands were absent in healthy controls (Fig. 2A). The electron microscope showed viroplasma containing virus-like particles in the parenchyma phloem cells. The particles were approximately 55 to $60 \mathrm{~nm}$ in diameter, some of them looking empty (incomplete particles) while others had an electron-dense core surrounded by an electron lucent layer (complete particles; Fig. 2B). The characteristics and size of the particles observed are similar to those reported for MRCV (21) and other fijiviruses $(7,12)$. Table 1 summarizes the results of the DAS-ELISA test for the evaluation of disease incidence. Mal de Río Cuarto was detected in the majority of the wheat plots assessed in the first year of the study, with frequency values between 2.5 and $17.5 \%$, while in the 1994 season, frequency increased to $24 \%$.

Previously, other fijiviruses have been reported as affecting wheat, in natural infections. Among them are oat sterile dwarf virus, which belongs to the subgroup III of the fijiviruses but is serologically unrelated to the rest of the group and has a quite different electrophoretic pattern from that of other known fijiviruses. (2,7); and rice black streak dwarf virus which, according to Azuhata et al. (1), should be considered as a geographical variant of MRDV. Both these viruses induce milder symptoms in wheat than those described for the MRCV $(3,28,31)$. MRDV has been cited only in artificial infections of wheat (18).

As a result of the positive reaction in the DAS-ELISA serological technique, the

Table 1. Mal de Río Cuarto incidence in wheat plots in the Río Cuarto Department (Córdoba Province, Argentina) in 1993 and 1994

\begin{tabular}{lccc}
\hline Locality & Year of sampling & Plot number & \% $^{\text {infection }}$ \\
\hline Río Cuarto & 1993 & 1 & 2.4 \\
Río Cuarto & 1993 & 2 & 3.9 \\
Río Cuarto & 1993 & 3 & 16.6 \\
Río Cuarto & 1993 & 4 & 0.0 \\
Río Cuarto & 1993 & 5 & 0.0 \\
La Carlota & 1993 & 6 & 6.0 \\
Sampacho & 1993 & 7 & 4.5 \\
Sampacho & 1993 & 8 & 9.5 \\
Sampacho & 1993 & 9 & 17.4 \\
Sampacho & 1993 & 10 & 6.6 \\
Sampacho & 1994 & 12 & 3.5 \\
Sampacho & 1994 & 13 & 24.1 \\
Espinillo & 1994 & 14 & 0.0 \\
Las Vertientes & 1994 & 3.3 \\
\hline
\end{tabular}

a Determined by double-antibody sandwich enzyme-linked immunosorbent assay. 
appearance of the 10 RNA fragments, and the virus particles observed in electron micrographs of ultra-thin sections, it may be concluded that the wheat plants with the described symptoms were infected with the Mal de Río Cuarto virus. This is the first time this fijivirus has been observed in wheat.

Symptom severity, as well as the infection levels registered in the fields, which reached values of $24 \%$, indicate that this is an important disease in wheat. This crop would also appear to be acting as a winter reservoir for the virus. If we add to this its role as a preferred habitat for the development of D. kuscheli (the main vector of the virus), there is a clear need to look for strategies for disease control in wheat, in the endemic area of the Mal de Río Cuarto, in order to reduce its incidence.

\section{ACKNOWLEDGMENTS}

We thank INTA, CONICET, and PROMARC (Proyecto Mal de Río Cuarto) for financial support for this project.

\section{LITERATURE CITED}

1. Azuhata, F., Uyeda, I., Kimura, I., and Shikata, E. 1993. Close similarity between genome structures of rice black streaked dwarf and maize rough dwarf viruses. J. Gen. Virol. 74:1227-1232

2. Boccardo, G., and Milne, R. G. 1980. Oat sterile dwarf virus. Description of Plant Virus No. 217. Commonw. Mycol. Inst. Assoc. Appl. Biol., Kew, Surrey, England.

3. Choi, Y. H., Lee, S. H., and Ryu, G. H. 1989. Studies on the host range of rice black streaked dwarf virus. Research Reports of the Rural Development Administration, Korea Republic. Crop Prot. 31(1):14-18.

4. Clark, M. E., and Adams, A. N. 1977. Characteristics of microplates methods of enzymelinked immunosorbent assay for detection of plant viruses. J. Gen. Virol. 34:475-483.

5. Conci, L. R., and Marzachi, C. 1993. Avances en la caracterización molecular del genoma del virus causal del "Mal de Río Cuarto." Pages 27-28 in: Actas Workshop "Mal de Río Cuarto del Maíz." Córdoba, Argentina.

6. Conti, M. 1988. Recent research on leafhopper vectors of plant virus and mycoplasmas at the Plant Virus Institute - Turin. Pages 447457 in: Proc. 6th Auchen Meeting, Torino, Italy.

7. Francki, R. I. B., Milne, R. G., and Hatta, T. 1985. Atlas of plant viruses, Vol No. 1. CRC Press Inc., Boca Raton, FL.
8. Giménez Pecci, M. P., Conci, L. R., Valdivia, B., Conci, V. C., Hoop, H. E., Laguna, I. G., and Nome, S. F. 1991. Algunas alternativas de diagnóstico del Virus del "Mal de Río Cuarto" (Maize Rough Dwarf Virus-MRDV). Pages 78-86 in: Actas Taller de Actualización sobre Mal de Río Cuarto. Pergamino, Argentina

9. Giménez Pecci, M. P., Laguna, I. G., Dagoberto, E., and Truol, G. A. 1993. Avena sativa $\mathrm{L}$, hospedante natural del virus causal del "Mal de Río Cuarto" del maíz. Pages 59-60 in: Actas Workshop "Mal de Río Cuarto del Maíz.” Córdoba, Argentina.

10. Giorda, L. M., Ornaghi, J. A., and Boito, G. T. 1993. Identificación de germoplasma de sorgo resistente al Mal de Río Cuarto. Pages 70-71 in: Actas Workshop "Mal de Río Cuarto del Maíz." Córdoba, Argentina.

11. Giordano, M. O., Basnec, S. N., Nates, S. V., Bennun, F., and Depetris, A. R. 1991. Rapid techniques for diagnostic and epidemiological studies of rotavirus infection. J. Virol. Methods 35:59-63.

12. Kurstak, E. 1981. Handbook of Plant Virus Infections, Chap 15: Comparative diagnosis. Elsevier, The Netherlands.

13. Laguna, I. G., Conci, L. R., Valdivia, B., Giménez Pecci, M. P., Altamira, C., and Trumper, E. 1991. Epidemiología del virus del "Mal de Río Cuarto" (Maize Rough Dwarf Virus). Pages 16-43 in: Actas Taller de Actualización sobre Mal de Río Cuarto. Pergamino, Argentina

14. March, G. J., Ornaghi, J. A., Beviacqua, J. E., and Marinelli, A. 1993. Intensidad del Mal de Río Cuarto y pérdidas causadas a la producción de maíz en las campañas agrícolas 1981/82 a 1991/92. Gac. Agronómica XIII (76):384-388.

15. March, G. J., Ornaghi, J. A., Beviacqua, J. E., Sanchez, G., and Guiggia, J. 1993. Aportes para el desarrollo de una estrategia de manejo del Mal de Río Cuarto. Pages 47-48 in: Actas Workshop "Mal de Río Cuarto del Maíz." Córdoba, Argentina

16. Marinelli, A., Muñoz, J. O., Lenardon, S. L., and Martino, C. A. 1988. Detección de un Reovirus semejante al causal del Mal de Río Cuarto del maíz en sorgo de alepo (Sorghum halepense $\mathrm{P}$ ) y mijo (Panicum milliaceum $\mathrm{L}$ ) (Abstr.) Actas II Jornadas de Investigación UN Nac. de Córdoba. Córdoba, Argentina

17. Marinelli, A., Muñoz, J. O., and Martino, C. A. 1991. Estudios sobre nuevos hospedantes naturales del Maize Rough Dwarf Virus-RC. Page 44 in: Actas Taller de Actualización sobre Mal de Río Cuarto. Pergamino, Argentina.

18. Milne, R. G., and Lovisolo, O. 1977. Maize rough Dwarf and related viruses. Adv. Virus Res. 21:267-341.

19. Milne, R. G., Boccardo, G., Dal Bo, E., and Nome, S. F. 1983. Association of Maize
Rough Dwarf Virus with Mal de Río Cuarto In Argentina. Phytopathology 73(9):12901292.

20. Muñoz, J. O., Giorda, L. M., and Calella, G. 1991. Estudios ultraestructurales de tejidos neoplásicos de sorgo afectados por Reovirus y Maize Dwarf Mosaic Virus. Page 100 in: Actas Taller de Actualización sobre Mal de Río Cuarto. Pergamino, Argentina

21. Nome, S. F., Lenardon, S. L., Raju, B. C. Laguna, I. G., Lowe, S. K., and Docampo, D. 1981. Association of Reovirus-like particles with "Enfermedad de Río Cuarto" of maize in Argentina. Phytopathol. Z. 101:7-15.

22. Nome, S. F., Lenardon, S. L., Muñoz, J. O., and Zumelzu, G. 1983. Digitaria sanguinalis (L.) Scop y Setaria verticillata (L.) Beauvois reservorios naturales del virus causal del Ma de Río Cuarto del maíz. RIA18:321-328.

23. Ornaghi, J. A., Boito, G. T., Sanchez, G., and March, G. J. 1993. Estudio de las poblaciones de Delphacodes kuscheli Fennah en avena, trigo y centeno. Pages 39-40. in Actas Workshop "Mal de Río Cuarto del Maíz." Córdoba, Argentina.

24. Ornaghi, J. A., Boito, G., Sanchez, G., March, G. J., and Beviacqua, J. E.; 1993. Studies on the populations of Delphacodes kuscheli Fennah, in different years and agricultural areas. J. Genet. Breed. 47:277-282.

25. Ornaghi, J. A., Marinelli, A. D., March, G. J. Boito, G., and Rodriguez Pardina, P. E. 1993. Transmisión del virus causal del Mal de Río Cuarto por Delphacodes kuscheli Fennah en cultivos y malezas. Pages 41-42 in: Actas Workshop "Mal de Río Cuarto del Maíz." Córdoba, Argentina

26. de Remes Lenicov, A. M., Teson, A., Dagoberto, E., and Huguet, N. 1985. Hallazgo de uno de los vectores del Mal de Río Cuarto en maíz. Gac. Agropecuaria V (25):251-258.

27. Rodriguez Pardina, P. E., and Laguna, I. G. 1993. Determinación de hospedantes naturales del virus causal del "Mal de Río Cuarto" en el área endémica de la enfermedad. Pages 55-56 in: Actas Workshop "Mal de Río Cuarto del Maíz." Córdoba, Argentina.

28. Shikata, E. 1974. Rice black streaked dwarf virus. Description of Plant Virus No. 135 Commonwealth Mycological Institute, Association of Applied Biologists, Kew, Surrey, England.

29. Spurr, A. R. 1969. A low viscosity epoxy resin embedding medium for electron microscopy. J. Ultrastruct. Res. 26:31-43.

30. Uyeda, I., and Milne, R. G. 1995. Introduction: genomic organization, diversity and evolution of plant Reoviruses. Semin. Virol. 6 (2):85-88

31. Wiese, M. V. 1987. Compendium of wheat diseases, second edition. American Phytopathological Society, St. Paul, MN. 